\title{
How (Epi)Genetic Regulation of the LIM-Domain Protein FHL2 Impacts Multifactorial Disease
}

\author{
Jayron J. Habibe ${ }^{1,2,+}$, Maria P. Clemente-Olivo ${ }^{1,+}$ (i) and Carlie J. de Vries ${ }^{1, *(\mathbb{C})}$ \\ 1 Department of Medical Biochemistry, Amsterdam University Medical Centers, Amsterdam Cardiovascular \\ Sciences, and Amsterdam Gastroenterology, Endocrinology and Metabolism, \\ 1105 AZ Amsterdam, The Netherlands; j.j.habibe@amsterdamumc.nl (J.J.H.); \\ m.p.clemente@amsterdamumc.nl (M.P.C.-O.) \\ 2 Department of Physiology, Amsterdam University Medical Centers, Amsterdam Cardiovascular Sciences, \\ 1081 HV Amsterdam, The Netherlands \\ * Correspondence: c.j.devries@amsterdamumc.nl \\ + These authors contributed equally to this review.
}

Citation: Habibe, J.J.; ClementeOlivo, M.P.; de Vries, C.J. How (Epi)Genetic Regulation of the LIM-Domain Protein FHL2 Impacts Multifactorial Disease. Cells 2021, 10, 2611. https://doi.org/10.3390/ cells10102611

Academic Editor: Mohamed Zaiou

Received: 27 August 2021

Accepted: 24 September 2021

Published: 1 October 2021

Publisher's Note: MDPI stays neutral with regard to jurisdictional claims in published maps and institutional affiliations.

Copyright: (C) 2021 by the authors Licensee MDPI, Basel, Switzerland. This article is an open access article distributed under the terms and conditions of the Creative Commons Attribution (CC BY) license (https:// creativecommons.org/licenses/by/ $4.0 /)$.

\begin{abstract}
Susceptibility to complex pathological conditions such as obesity, type 2 diabetes and cardiovascular disease is highly variable among individuals and arises from specific changes in gene expression in combination with external factors. The regulation of gene expression is determined by genetic variation (SNPs) and epigenetic marks that are influenced by environmental factors. Aging is a major risk factor for many multifactorial diseases and is increasingly associated with changes in DNA methylation, leading to differences in gene expression. Four and a half LIM domains 2 (FHL2) is a key regulator of intracellular signal transduction pathways and the FHL2 gene is consistently found as one of the top hyper-methylated genes upon aging. Remarkably, FHL2 expression increases with methylation. This was demonstrated in relevant metabolic tissues: white adipose tissue, pancreatic $\beta$-cells, and skeletal muscle. In this review, we provide an overview of the current knowledge on regulation of FHL2 by genetic variation and epigenetic DNA modification, and the potential consequences for age-related complex multifactorial diseases.
\end{abstract}

Keywords: obesity and related metabolic diseases; epigenetic marks; transcription factors; metabolic diseases; gene expression

\section{Introduction}

Four and a half LIM domains 2 (FHL2) was originally described as 'Down-regulated in Rhabdomyosarcoma LIM protein' (DRAL) and is composed of LIM domains that are named after their initial discovery in the proteins Lin11, Isl-1 and Mec-3 [1]. FHL2 consists of four and a half LIM domains, each composed of two zinc fingers, except the first 'half' LIM-domain which has only one. While the structure of the four and a half LIM domains had been uncovered previously using Nuclear Magnetic Resonance (NMR) spectroscopy, the complete FHL2 protein structure is unknown; however, it has recently been predicted using the protein structure neural network AlphaFold (Figure 1) [2].

The LIM domains allow FHL2 to interact with a variety of other proteins, resulting in an impressive interactome comprising more than 92 targets known to date [3]. Upon binding of FHL2, the conformation of target proteins may alter and consequently their post-translational modifications, their cellular localization, or their interactions with other proteins may change. Thus, FHL2 acts as a scaffold protein and can adjust the structure, activity, and function of its interaction partners. In contrast to the findings regarding many zinc fingers which indicate their ability to bind to DNA, the zinc-fingers of FHL2 lack this ability. Therefore, FHL2 does not directly regulate gene expression. However, FHL2 is of course still able to regulate gene expression via interaction with transcription factors and their upstream co-regulators [4]. Through binding to its target proteins, FHL2 modulates 
and fine-tunes signal transduction pathways and subsequent gene regulation, which is important in the function of various tissues and their pathologies.

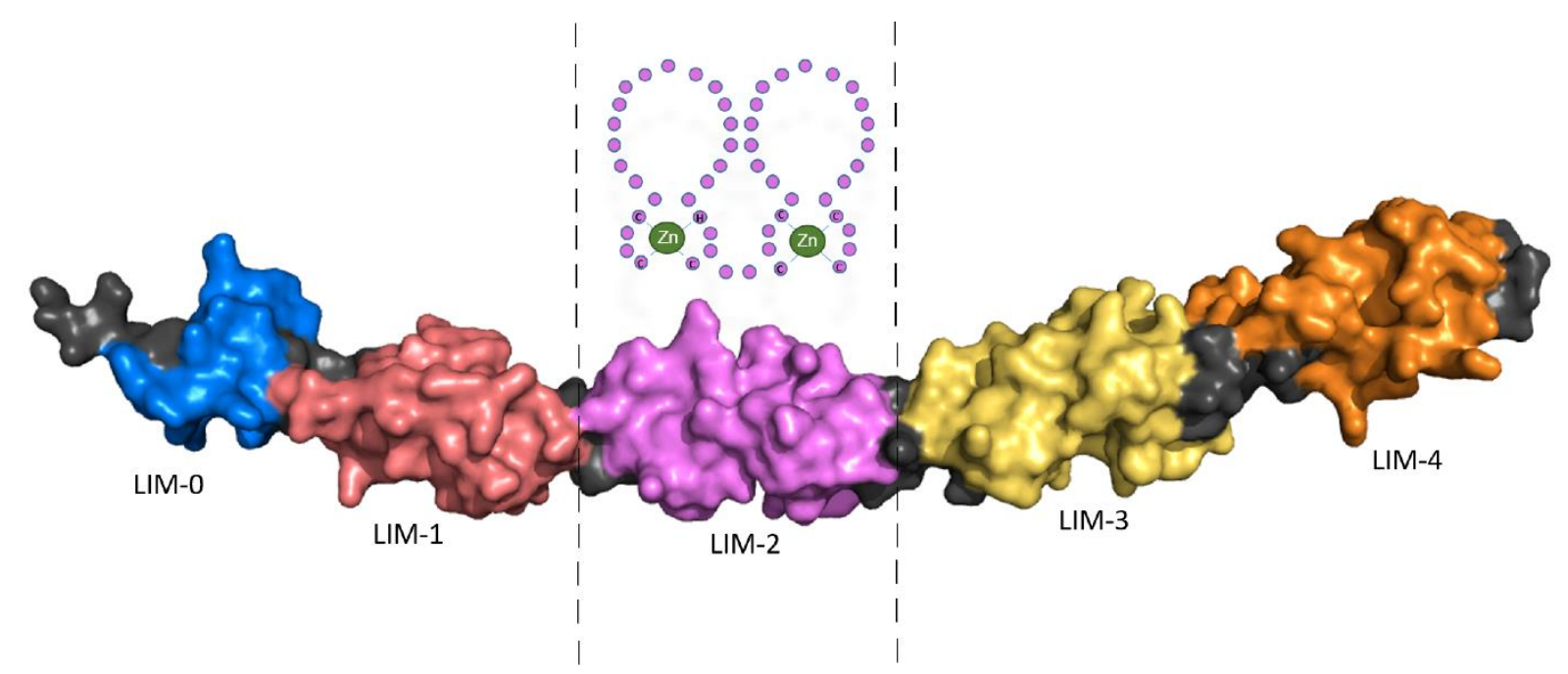

Figure 1. Schematic representation of LIM domain 2 (LIM-2) composed of two zinc fingers, above, with the complete protein structure of FHL2 based on X-ray structures of the independent LIM domains and Alphascreen computation (AF-Q14192-F1-model_v1.PDB: https:/ /alphafold.ebi.ac.uk/). Accessed in July 2021.

FHL2 is expressed most abundantly in the heart, blood vessels, ovary, and skeletal muscle, and to a lesser extent in several other organs [5-8]. FHL2 expression and function have been studied in a number of diseases, including various types of cancer [9-12], cardiovascular disease [5,6,8,13-15], and overall metabolism [16]. At present, information regarding the exact regulation of FHL2 expression is limited $[17,18]$. Several genome-wide association studies (GWAS) have shown association between FHL2 single nucleotide polymorphisms (SNPs) and complex diseases and traits [19-21]. While informative, FHL2 SNPs alone are unlikely to be sufficient to elucidate the role of FHL2 in complex multifactorial traits and maladies.

Growing evidence supports the notion that epigenetics, and in particular DNA methylation, mediates the connection between environment and gene expression across the human body. The human DNA methylation pattern or 'methylome' shows considerable variation and is indeed responsive to environmental cues [22]. Actually, several risk factors for disease such as age, unhealthy diet or exposure to chemical agents play a decisive role in the methylation status of the genome [23]. The FHL2 gene contains a number of methylation-prone $\mathrm{CpG}$ sites that have repeatedly been shown to become methylated with age and which are involved in the regulation of FHL2 expression.

These methylated FHL2 CpG sites have also been shown to be quite consistently present in different tissues, while demonstrating significant correlations with aging [24-26]. These recent findings suggest a potentially pivotal role for methylation in regulating FHL2 expression and function in age-related disorders.

\section{FHL2 Tissue Expression}

FHL2 was initially discovered as one of the genes strongly down-regulated during transformation of healthy primary myoblasts into rhabdomyosarcoma tumor cells [27]. Next, it was shown that FHL2 is expressed in multiple tissues, with the highest expression level found in the heart [28]. However, substantial levels of expression are also present in the ovaries, testes, prostate, and intestine (Figure 2). The relatively high FHL2 expression in the heart explains why its function has been the subject of extensive study in this organ. In early embryonic development FHL2 is already present in the heart, and it remains there into adulthood in both mice and humans. FHL2 is dispensable for normal development of the heart in mice, as illustrated by the observation that the heart matures normally in 
FHL2-deficient mice [13]. In adult mice, FHL2 deficiency causes an increased hypertrophic response in cardiac disease models such as $\beta$-adrenergic stimulation to provoke cardiac hypertrophy or the coronary artery ligation model to induce ischemia $[28,29]$.

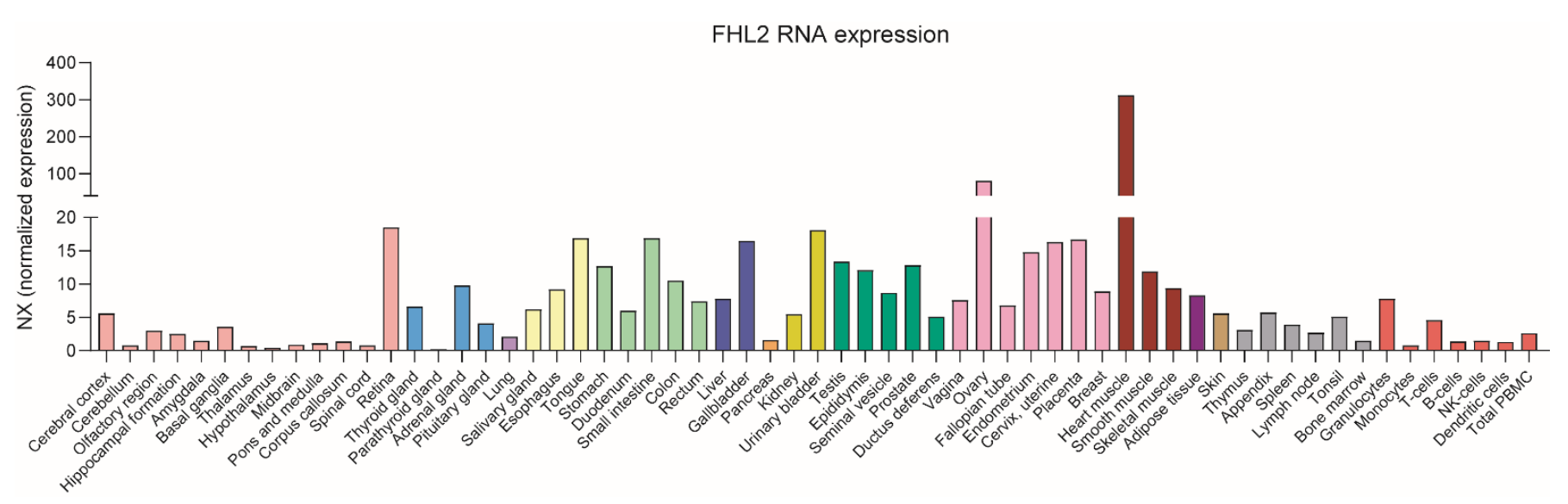

Figure 2. Normalized FHL2 mRNA expression in multiple tissues. Based on transcriptomic data from three sources: HPA, GTEx, and FANTOM5 (Protein Atlas: https://www.proteinatlas.org/). Accessed in July 2021.

In skeletal muscle, FHL2 promotes differentiation of myoblasts and is involved in autophagy $[7,30]$. It is expressed in almost all areas of the developing brain but restricted to particular regions postnatally, mainly the cortex [31,32]. It was demonstrated that FHL2 deficiency affects neuroblast migration, resulting in accumulation of specific astrocytes in the brain of mice. Furthermore, FHL2 plays a role in ocular vascularization [33]. Based on experiments in FHL2-knockout (KO) mice it was concluded that FHL2 promotes corneal angiogenesis by inhibiting local inflammation. In the liver FHL2 levels are relatively low, but upon overexpression in this organ in mice the balance of hepatocyte proliferation and apoptosis is disturbed, leading to inflammation and cirrhosis. Furthermore, in FHL2-KO mice the liver shows increased fibrosis and an exacerbated response in a cholestatic injury model [34-36]. FHL2 has been detected in kidney podocytes where it interacts with and activates the Wnt/ $\beta$-catenin signaling pathway [37]. Intriguingly, though $F H L 2$ is not highly expressed in either spleen or immune cells, it is found to regulate inflammation in stressed or injured tissues [38,39]. Atherosclerosis, which may be considered a chronic inflammation of the vessel wall, was studied in FHL2-KO mice; these developed smaller atherosclerotic plaques after a cholesterol-enriched diet. This can be at least partly explained by decreased chemokine production resulting in reduced monocyte recruitment to the vessel wall [40,41]. Conflicting data have been reported on the function of FHL2 in vascular smooth muscle cells in regulation of proliferation, inflammation, and cholesterol efflux of these cells, which has been reviewed before [4,5,8,42].

Bacos et al. revealed that age-dependent DNA methylation of the FHL2 gene correlates with increased FHL2 expression in human pancreatic islets [38]; this will be described in more detail in the paragraph on FHL2 methylation below. A similar pattern was observed in adipose tissue, with enhanced DNA methylation of the FHL2 gene resulting in higher expression levels [43]. FHL2 expression in adipose tissue correlates with increased body mass, and it has recently been demonstrated that FHL2-KO mice are resistant to weight gain involving increased 'browning' of white adipose tissue [16].

In a number of cancer cells, FHL2 protein has been described to function either as a tumor suppressor or as an oncoprotein. Basal and stimulated expression of FHL2 appears to be highly influenced by the tumor cell type, tumor origin, and context $[44,45]$. Furthermore, FHL2 plays distinct roles in breast, ovarian, and prostate cancer through its interaction and regulation of transcription factors such as the estrogen and androgen receptor [12,46-49]. FHL2 expression and function also varies in cancer of the liver, tongue and gastrointestinal 
tract [50-53]. The complicated role of FHL2 in cancer will not be described in further detail in this review.

\section{Regulation of $\boldsymbol{F H L 2}$ Expression by Specific Transcription Factors}

There is only limited information concerning the regulation of FHL2 gene expression by specific transcription factors. Using chromatin-immunoprecipitation (ChIP), the tumor suppressor protein p53 has been demonstrated to induce FHL2 expression through selective binding of a response element localized in one of the two alternative promoters of FHL2 [50]. Specificity protein 1 (SP1), an essential transcription factor in many cancer cells, has also been shown to regulate FHL2 expression by binding upstream of the FHL2 transcription start site [54]. In hepatocellular carcinoma cells, expression of the proteins Paired Box 5 (PAX5) and Zinc Finger Protein 5 Homolog (ZFP5) positively correlate with FHL2 expression, while potential binding sites for these proteins were found in the FHL2 promoter sequence [17]. Similarly, Myocyte Enhancer Factor 2 (MEF2), a transcription factor relevant in cardiac and skeletal muscle, has a potential binding site in the FHL2 promoter and shows expression overlapping with FHL2 in these tissues [32]. Furthermore, FHL2 is a target gene of Serum Response Factor (SRF), which together with its interaction partner, the Homeobox Protein Nkx2.5, regulates FHL2 expression [32,55]. In osteoclasts, FHL2 forms a complex with RUNX Family Transcription Factor 1 (RUNX1) and TNF Receptor Associated Factor 6 (TRAF6) to control its own expression via RUNX1 binding sites [18]. Another example of autoregulation involves Activator Protein 1 (AP1), a known FHL2 interactor, which binds and promotes expression of the FHL2 gene [56].

\section{FHL2 Genetic Variation}

At present, 22 FHL2 SNPs have been associated with a specific disease or trait: cardiac myopathy, pulse pressure, venous thrombosis, severity of bronchial hyper-responsiveness, acute myeloid leukemia, myeloid white cell count, platelet count, fat body mass, BMI, age of menopause, the electrocardiographic PR-interval of the heart, lung cancer in 'ever-smokers', smoking status, height, and unipolar depression. These data are summarized in Figure 3 and Table 1 and we will describe current knowledge about these FHL2 genetic variants in more detail. The two SNPs that are located in the coding region of the FHL2 gene are both synonymous variants not giving rise to amino-acid sequence changes. Furthermore, for the variants that are located in non-coding regions of the FHL2 gene, we envisage that they are either neutral, lead to alternative splicing of the FHL2 gene, and/or influence FHL2 expression.

Table 1. FHL2 SNPs and associated traits. The table denotes the FHL2 genetic polymorphisms that are associated with a disease or trait, according to the literature. Here, we indicate the reference allele (Ref), the alternative allele (Alt), the location of the SNP on chromosome 2 (Location), the associated trait, whether the SNP is within the coding, non-coding, or intergenic region (SNP type), and the reference article (Reference). SNPs rs3087523 and rs62155873 ( ${ }^{a}$ ), rs1401209, and rs7563316 $\left({ }^{b}\right)$ and rs3943516 and rs6741486 $\left(^{c}\right)$ are marked as they form LD pairs with each other, respectively (see also Figure 3).

\begin{tabular}{cccccccc}
\hline SNP ID & Ref & Alt & Risk Allele & Location & Associated Trait & SNP Type & Reference \\
\hline rs4851765 & C & T/A & NA & $2: 105396175$ & $\begin{array}{c}\text { Severity of bronchial } \\
\text { hyper-responsiveness }\end{array}$ & non-coding & [57] \\
rs114298934 & C & A & NA & $2: 105602735$ & Age of menopause & non-coding & [58] \\
rs4851770 & T & C & NA & $2: 105429876$ & Venous thrombosis & non-coding & {$[59]$} \\
rs186607487 & A & G & A & $2: 105391292$ & Fat body mass & non-coding & [60] \\
rs3087523 a & G & A & NA & $2: 105361319$ & BMI & Coding & [61] \\
rs11124029 & G & A & NA & $2: 105361304$ & Cardiac myopathy & coding & [63] \\
\hline
\end{tabular}


Table 1. Cont.

\begin{tabular}{|c|c|c|c|c|c|c|c|}
\hline SNP ID & Ref & Alt & Risk Allele & Location & Associated Trait & SNP Type & Reference \\
\hline rs1401209 b & $\mathrm{T}$ & G & $\mathrm{T}$ & $2: 105475760$ & & & \\
\hline rs9789507 & $\mathrm{T}$ & $\mathrm{C}$ & $\mathrm{C}$ & $2: 105477863$ & & & \\
\hline rs7563316 & $\mathrm{C}$ & $\mathrm{T}$ & $\mathrm{C}$ & $2: 105479257$ & & & \\
\hline rs17030964 & $\mathrm{C}$ & A & $\mathrm{C}$ & $2: 105477930$ & Acute myeloid leukemia & intergenic & [19] \\
\hline rs4851776 & G & $\mathrm{A}$ & $\mathrm{A}$ & $2: 105484430$ & & & \\
\hline rs2139109 & $\mathrm{C}$ & $\mathrm{T}$ & $\mathrm{C}$ & $2: 105475835$ & & & \\
\hline rs12997792 & $\mathrm{C}$ & $\mathrm{T}$ & $\mathrm{T}$ & 2:105485871 & & & \\
\hline rs13006682 & $\mathrm{T}$ & $\mathrm{C}$ & $\mathrm{C}$ & 2:105488399 & PR interval & intergenic & {$[64]$} \\
\hline rs17697383 & $\mathrm{C}$ & $\mathrm{A} / \mathrm{T}$ & $\mathrm{C}$ & 2:105454164 & Lung cancer in ever smokers & intergenic & [20] \\
\hline rs62155873 ${ }^{a}$ & $\mathrm{C}$ & $\mathrm{T}$ & NA & $2: 105352905$ & Smoking status & intergenic & [62] \\
\hline rs13410405 & $\mathrm{T}$ & G & G & $2: 105581084$ & Myeloid white cell count & intergenic & [65] \\
\hline rs3943516 ${ }^{c}$ & A & G & G & 2:105577095 & Platelet count & intergenic & $\begin{array}{l}{[65]} \\
{[66]}\end{array}$ \\
\hline rs6741486 ${ }^{c}$ & $\mathrm{~A}$ & G & G & $2: 105583173$ & Platelet count & intergenic & [65] \\
\hline rs111945524 & $\mathrm{C}$ & $\mathrm{T}$ & $\mathrm{T}$ & $2: 105482561$ & Unipolar depression & intergenic & {$[21]$} \\
\hline rs6738207 & G & A & NA & 2:105373259 & Height & non-coding & [62] \\
\hline rs150194832 & G & $\mathrm{C}$ & G & 2:105510423 & Pulse pressure & intergenic & [67] \\
\hline
\end{tabular}

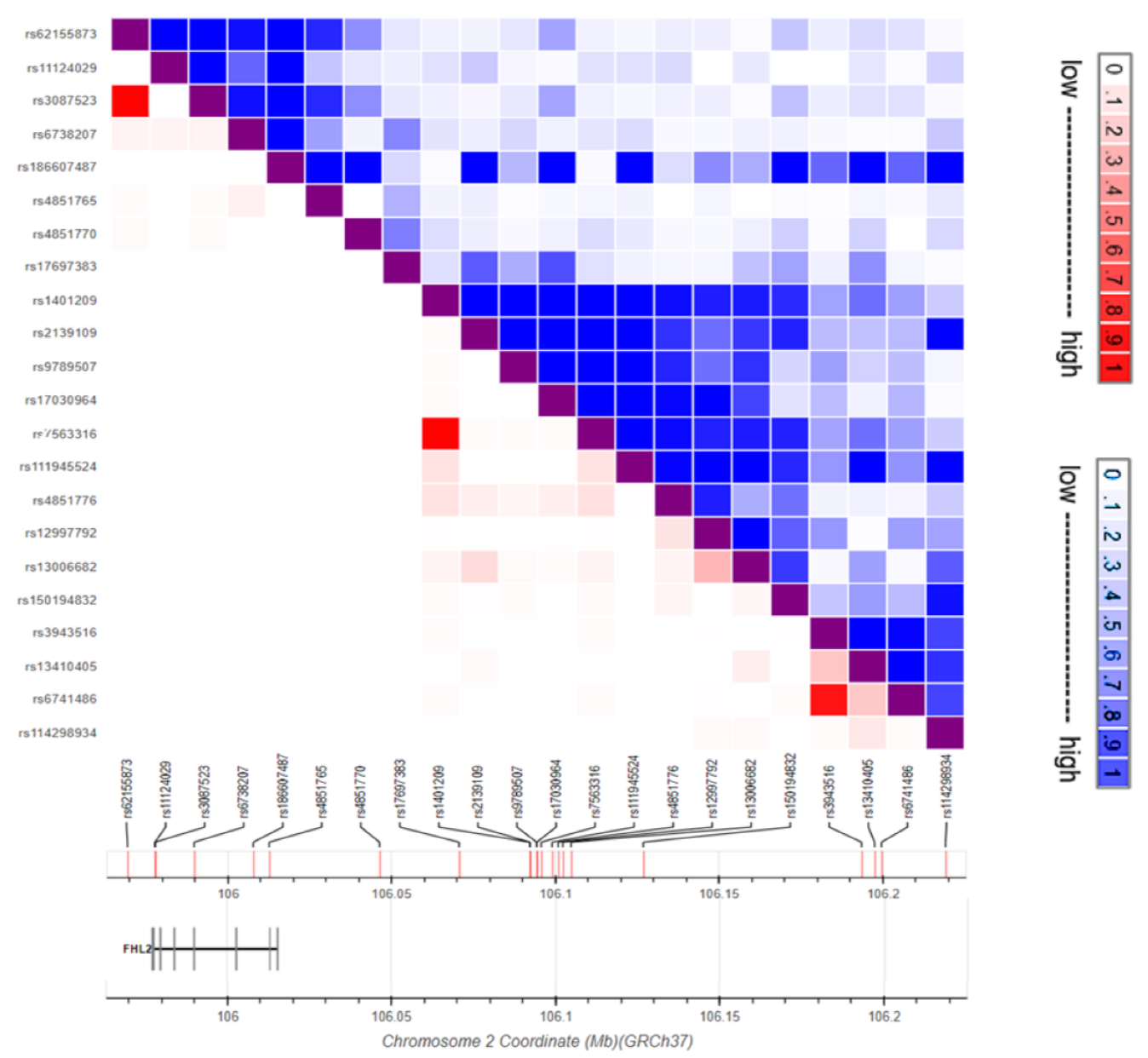

Figure 3. Schematic representation of SNPs in an LD matrix and their localization on chromosome 2, with the FHL2 gene indicated at the left (GrCh37). SNPs with high LDs are indicated in red $\left(\mathrm{R}^{2}\right)$ and blue $\left(\mathrm{D}^{\prime}\right)$. Figure adapted from LDlink.

\subsection{FHL2 SNPs and Metabolic Phenotypes}

There is an emerging focus on FHL2 function in the context of metabolism $[16,68]$, which is also reflected by the observation that rs3087523 and rs186607487 are associated 
with body mass index (BMI) and fat body mass, respectively (Table 1) [60-62]. In line with this observation, FHL2-deficient mice gain less weight than their wild-type littermates in response to a high-fat diet [16]. In the latter study, 'browning' of white adipocytes was observed in the mice upon FHL2 deficiency. Similar changes in gene expression were observed in human white adipose tissue. In humans, increased FHL2 expression is also associated with decreased expression of a number of the so-called 'browning genes', such as peroxisome proliferator-activated receptor gamma coactivator 1-alpha (PGC1a), cardiolipin synthase 1 (CRLS1), sirtuin 1 (SIRT1), peroxisome proliferator-activated receptor gamma (PPARG), and bone-morphogenic protein 7 (BMP7) [16]. Of note, the variants rs3087523 and rs62155873 are in high linkage disequilibrium (LD) and are both associated with BMI in the same study. In another study, rs3087523 was shown to associate with BMI (Figure 3) [61]. Kichaev et al. FHL2 revealed that the genetic polymorphism rs6738207 is associated with height. While this information is only present within the supplementary data, it is still of note as height is a major determinant of BMI and may be of interest to investigate further.

\subsection{FHL2 SNPS in Cardiovascular Disease and Lung Inflammation}

FHL2 has been studied extensively to determine its role in both the heart and the vasculature, as described above. Two FHL2 polymorphisms, rs3087523 and rs11124029, have been linked to hypertrophic cardiac myopathy [63]. So far, it is unknown for both of these variants which of their respective alleles is actually the risk allele associated with developing cardiac myopathy. Additionally, FHL2 polymorphisms rs13006682 and rs150194832 have been linked to the PR interval of the heart and pulse pressure, respectively [64,67].

The FHL2 genetic variant rs4851765 associates with the severity of bronchial hyperresponsiveness [57]. Here, the risk allele is also unknown, as rs4851765 has two alternative alleles. In line with this observation in humans, Kurakula et al. demonstrated that mice lacking FHL2 have a weakened airway inflammatory response in an allergenic respiratory inflammation mouse model.

\subsection{FHL2 SNPs in Coagulation and Cancer}

Kroone et al. demonstrated in mice that FHL2 deficiency enhances venous thrombosis. FHL2 interacts with Tissue Factor resulting in a reduction of its coagulation activity, and there is thus enhanced blood clot formation in FHL2-deficient mice. Furthermore, FHL2 SNP rs4851770 was shown to associate with the risk of developing venous thrombosis in humans [59]. Given the specific location of this SNP, it has been classified as an upstream transcript variant that forms part of intron 1 in two FHL2 transcript variants, but not in others. To date, two studies have shown an association between FHL2 SNPs and blood platelet count $[65,66]$. The relevant SNP variants are rs3943516 and rs6741486; both are located in the intergenic region upstream of the FHL2 gene (Table 1). These same variants are in LD and have additionally been associated with myelopoiesis and hematopoiesis [69]. As indicated above, FHL2 is often encountered in the context of oncology, and a large body of research implicates FHL2 in the development of leukemia [69-73]. Several of these studies showed that increased FHL2 expression correlates with poor prognosis of leukemia [69,70]. One GWAS has shown an association between FHL2 variants rs1401209, rs9789507, rs7563316, rs17030964, rs4851776, rs2139109, and rs12997792 and acute myeloid leukemia (Table 1) [19]. Of note, all these genetic loci are intergenic variants located outside of the FHL2 gene. McKay et al. revealed the association between FHL2 SNP rs17697383 and lung cancer in smokers [20]. While it was not their primary finding, it is still important to note that this SNP is associated with 'ever-smoking', with the major C-allele serving as the risk allele. FHL2 polymorphism rs62155873 is associated with smoking as well. 


\subsection{FHL2 SNPs and Diverse Traits}

Howard et al. performed a GWAS to identify genetic loci associated with depressionrelated phenotypes. As can be garnered from the supplementary data, FHL2 genetic locus rs111945524 is associated with broad depression [21]. FHL2 SNP rs114298934 was reported as an SNP that associates with age of menopause in a population enriched for longevity [58]. In this specific study, it was also reported that this genetic variation does not impact FHL2 gene expression.

Taken together, the 22 FHL2 genetic polymorphisms listed here show a range of associations with various metabolic, cardiovascular, and oncological diseases and traits, which are predominantly age-related conditions. While the role of the FHL2 SNPs in these fields is uncertain, given that they are either synonymous variants or located within the non-coding/ intergenic regions we can still conclude that the contribution of genetic variation in the FHL2 gene on its own in numerous phenotypes seems limited.

\section{Methylation of the FHL2 Gene}

DNA methylation is the best-known epigenetic modification of the genome, altering DNA accessibility and thereby regulating gene expression. It occurs when a methyl group is added enzymatically to a cytosine, usually forming part of a CG dinucleotide (CpG). Genomic regions where $\mathrm{CpG}$ dinucleotides or sites cluster are called $\mathrm{CpG}$ islands. They are usually located in the proximity of a promoter region. However, methylation of CpG sites can also occur in other areas such as exons, introns or intergenic regions [74]. Patterns of DNA methylation are constantly changing from early stages of development through physiological processes and pathological conditions, strongly influenced by the environment [23]. Actually, several environmental factors such as age, diet, physical activity, microbiota or exposure to chemical and physical agents play a major role in disease progression through the DNA methylation changes they produce in the genome [23,75]. In the next sections, we will summarize the current literature on DNA methylation of FHL2 and its relevance in aging and age-related diseases, including obesity and type 2 diabetes.

\subsection{Hyper-Methylation of FHL2 in Aging}

There is an "epigenetic clock", which consists of specific methylation changes located in particular loci of the human genome that can be found across multiple tissues, which individuals of the same age have in common [76]. Age-prediction is particularly useful in forensic science, where determination of the age of an individual in limited amounts of DNA is key. In a fascinating turn of events, a person's age can be assessed by determining the extent of methylation of specific CpG sites in the genome. In 2013, Hannum et al. developed a mathematical model for age prediction based on methylation of $71 \mathrm{CpG}$ sites in different genes, and since then efforts have been made to simplify and refine this biological age prediction tool [77]. One of the hyper-methylated loci most consistently found upon aging is located in the FHL2 gene, together with loci in Elongation of Very Long Chain Fatty Acids Protein 2 (ELOVL2), Kruppel-like factor 14 (KLF14) and Proenkephalin (PENK) [43,78-80]. More specifically, there is a region of clustered CpG sites (a CpG island) located proximal to the first exon of the FHL2 gene (Figure 4). The majority of FHL2 CpG sites found hyper-methylated with aging in multiple tissues are localized in this region of chromosome 2. The relevant CpG sites for FHL2 that have been described in more detail are summarized in Table 2 and Figure 4. Three methylation sites in the CpG island of FHL2 are included in the methylome-based age-prediction model: cg06639320, cg22454769 and cg24079702 [77]. A study comparing DNA methylation in blood from mother-offspring couples revealed these three sites within the top five most significantly methylated CpG sites. This result was further confirmed in larger cohorts including males and females from a wide age range (9-99 years old) or middle-aged individuals [26,78,81]. Recently, forensic studies have expanded the use of the age-prediction tool to other samples apart from blood, such as saliva, bone or buccal swabs, and also confirmed its use in living and deceased individuals. In all of the samples except buccal swabs, at least one of the aforementioned 
three CpG sites for FHL2 is consistently used as part of the array of CpG sites used for age determination $[79,82-87]$. Even though a study performed in bone alone did not find a significant correlation of age to FHL2 methylation sites [25], in teeth, the methylation of $8 \mathrm{CpG}$ sites in FHL2, together with sites in ELOVL2 and PENK, can accurately predict age [88]. An additional tissue where FHL2 methylation on cg22454769 was found to correlate with age is skeletal muscle [89]. Some pathologies are closely associated with accelerated cell aging and deterioration, such as Alzheimer's Disease and Grave's Disease, distorting the link between biological and chronological age. To evaluate the age prediction accuracy of reported methylation-based age-prediction markers, among which is FHL2, the methylation pattern of individuals who suffer from these two diseases was analyzed in blood. Patients with Alzheimer's Disease showed normal FHL2 methylation, whereas in the blood of patients with Grave's Disease a marked hypomethylation was found for one of the FHL2 CpG sites [90]. Exposure to certain chemicals is known to affect DNA methylation and is also associated with disease development. Among the toxic compounds to which many individuals are continuously exposed are polycyclic aromatic hydrocarbons (PAHs), which increase the risk of cancer. Li et al. hypothesized that long-term exposure to PAH accelerates aging through increased methylation, which was confirmed by correlation of PAH presence in urine samples and hyper-methylation of FHL2 and ELOVL2 in an individual's leukocytes. Interestingly, in this study increased methylation of FHL2 at cg22454769 was in line with increased expression [91]. Finally, a very extensive study performed in several tissues and cell lines aimed to evaluate the capacity of FHL2 and ELOVL2 to predict age. In order to do this, some previously reported CpG sites from both genes were used as probes (for FHL2 these were cg06639320, cg22454769, cg24079702, cg26344233, and cg06907053), and samples from individuals with a wide range of age were tested. Though a consistent linear trend of hyper-methylation could be seen for FHL2 across the majority of tissues, in blood only site cg06639320 significantly correlated to age [92].

\section{FHL2}

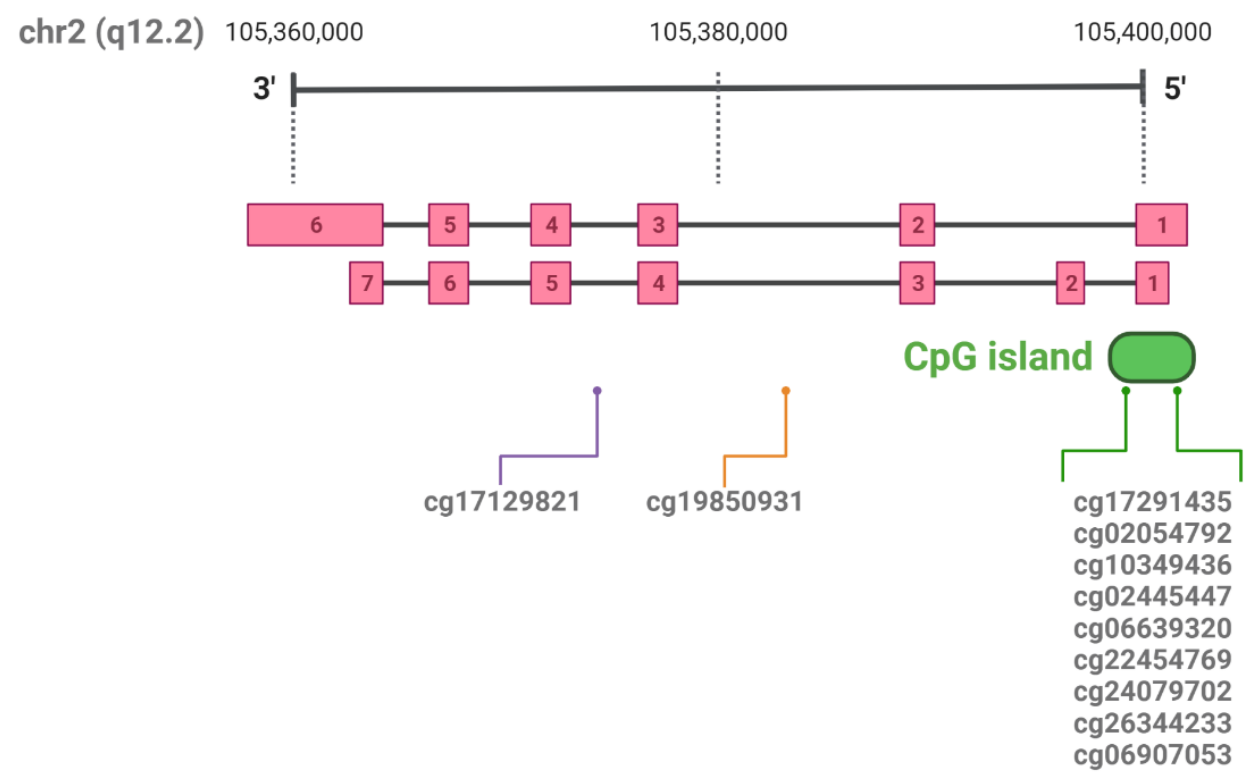

Figure 4. Schematic representation of $F H L 2$ transcript variants (exons are sequentially numbered) and relevant CpG sites, according to Genome Browser (GRCh38/hg38 and GRCh37/hg19). Created with BioRender.com. 
Table 2. Table of CpG sites in the FHL2 gene found in the literature. Position in chromosome based on genome version ${ }^{\text {a }}$ GRCh37/hg19 or ${ }^{\text {b }}$ GRCh38/hg38.

\begin{tabular}{|c|c|c|c|}
\hline CpG ID & $\begin{array}{l}\text { Position in } \\
\text { Chromosome }\end{array}$ & Tissue & References \\
\hline $\operatorname{cg} 17129821$ & chr2:105986385 a & Liver & [93] \\
\hline \multirow{2}{*}{ cg19850931 } & \multirow{2}{*}{$\operatorname{chr} 2: 105993347^{\mathrm{a}}$} & Whole blood & [43] \\
\hline & & Adipose tissue & [43] \\
\hline cg17291435 & chr2:106015527 a & Liver & [93] \\
\hline cg02054792 & $\operatorname{chr} 2: 106014950^{a}$ & Liver & [93] \\
\hline cg10349436 & chr2:106015079 a & Adipose tissue & [43] \\
\hline \multirow[t]{4}{*}{ cg02445447 } & chr2:106015595 a & Liver & [93] \\
\hline & & Whole blood & {$[68,78,81,83,85]$} \\
\hline & & Pancreatic islets & [68] \\
\hline & & Leucocytes & [94] \\
\hline \multirow[t]{7}{*}{$\operatorname{cg} 06639320$} & $\operatorname{chr} 2: 106015740^{a}$ & Granulocytes & [92] \\
\hline & & Liver & [93] \\
\hline & & Lymphoblastoid line & [95] \\
\hline & & Saliva & [24] \\
\hline & & Whole blood & {$[68,78,81,83,85]$} \\
\hline & & Adipose tissue & [43] \\
\hline & & Pancreatic islets & [68] \\
\hline \multirow[t]{6}{*}{$\operatorname{cg} 22454769$} & $\operatorname{chr} 2: 106015768^{a}$ & Leucocytes & [94] \\
\hline & & Granulocytes & [92] \\
\hline & & Liver & [93] \\
\hline & & Skeletal muscle & [89] \\
\hline & & Whole blood & {$[68,78,81,83,85]$} \\
\hline & & Pancreatic islets & [68] \\
\hline \multirow[t]{3}{*}{ cg24079702 } & $\operatorname{chr} 2: 106015772^{a}$ & Leucocytes & [94] \\
\hline & & Granulocytes & [92] \\
\hline & & Liver & [93] \\
\hline \multirow{3}{*}{ cg26344233 } & \multirow{3}{*}{ chr2:106015818 a } & Whole blood & [43] \\
\hline & & Adipose tissue & [43] \\
\hline & & Whole blood & [43] \\
\hline \multirow[t]{2}{*}{$\operatorname{cg} 06907053$} & \multirow[t]{2}{*}{ chr2:106015870 a } & Adipose tissue & [43] \\
\hline & & Liver & [93] \\
\hline Not specified (8 CpG sites) & chr2: $106015678-106016008^{a}$ & Teeth & [88] \\
\hline Not specified (12 CpG sites) & chr2:105399282-105399340 b & Whole blood & [82] \\
\hline Not specified & chr2:105399282 b & Whole blood & [86] \\
\hline Not specified & chr2:105399291 b & Whole blood & [79] \\
\hline
\end{tabular}

\subsection{Hyper-Methylation of FHL2 in Metabolism}

BMI, Hba1c (a marker for diabetes), and epigenetic changes have been evaluated in human white adipose tissue and compared to the methylome in blood from the same individuals. Four CpG sites of FHL2 were found to be associated with age in both blood and subcutaneous white adipose tissue in a male cohort; this concerns cg06907053, cg26344233 and cg10349436, located within the CpG island, and cg19850931, located in an intronic region. An additional site (cg22454769) was found hyper-methylated in the female validation cohort only [43]. It is important to stress again that hyper-methylation of the FHL2 gene correlates with increased FHL2 expression, which is rather uncommon as, in general, hyper-methylation of genes causes gene-silencing. In white adipose tissue, FHL2 expression increases with methylation, as already mentioned above, which was also observed in blood and pancreatic islets of healthy and type 2 diabetic subjects [68]. More specifically, in the latter study hyper-methylation of cg06639320 and cg22454769 CpG sites was shown to correlate positively with age and FHL2 expression. The same group studied methylation in the liver and compared this to blood methylomes of individual donors. This resulted in a list of $16 \mathrm{CpG}$ sites, in which FHL2 was not included. Yet, eight different CpG sites in FHL2 were found significantly more methylated in the aged liver; the aforementioned 
cg06639320, cg22454769 and cg24079702, as well as cg06907053, one of the sites also found in white adipose tissue, and four additional CpG sites: cg02054792, cg02445447, cg17291435, cg17129821 [93].

Taken together, and considering the increasing number of studies based on the epigenetic clock, we can conclude unequivocally that methylation of the FHL2 gene is associated with aging and is an important marker in age-related prediction tools. Furthermore, there is the highly interesting situation that hyper-methylation of CpG sites in the promoter region of FHL2 seems to provoke increased gene expression. Even though in many cases DNA methylation of a promoter region inhibits the binding of transcription factors, thus silencing gene expression, this turns out to be less of a universal mechanism than previously thought. Advances in sequencing techniques have indeed uncovered that a large proportion of hyper-methylated regions correlate positively with gene expression [75,96]. Most likely, though still unproven, methylation of the FHL2 promoter region interferes with binding of inhibitory DNA-binding factors, thereby facilitating gene expression.

\section{Concluding Remarks and Perspective}

An impressive number of studies have been performed to unravel the function of the protein-protein interactor FHL2 in several pathologies, ranging from cardiac dysfunction and vascular disease to cancer and obesity. In addition, as documented here, epigenetic and, to a lesser extent, genetic variation in FHL2 correlates with specific diseases and traits. FHL2-deficient mice have been instrumental in assessing the functional involvement of FHL2 in these (patho)physiological processes.

Taking the data on (epi)genetic modification and function of FHL2 together, it is indisputable that hyper-methylation at specific $\mathrm{CpG}$ sites in the promoter region of the FHL2 gene is associated with human aging. Unexpectedly, increased methylation of FHL2 coincides with enhanced expression of this protein. So far, no data are available on whether, in addition to this epigenetic regulation of FHL2 gene expression, genetic variation also modifies FHL2 splicing and/or expression. Furthermore, we conclude that, in mice, FHL2 has a beneficial function in cardiac hypertrophy, skin and intestinal wound healing, corneal angiogenesis and cholestatic injury of the liver. This comes at a price, however, as high FHL2 expression worsens the outcome of atherosclerosis and acute myeloid leukemia, as well as obesity and white adipose tissue function. Especially for atherosclerosis, cancer and obesity, aging is a well-known and severe risk factor. While the function of FHL2 is multi-faceted and ambiguous, these data collectively point towards a central and perhaps even fundamental role for FHL2 in the complex mechanism of aging and in its associated illnesses. In conclusion, detailed knowledge of the human methylome may lead to a better understanding of age-related molecular pathways that predispose individuals to obesity and its comorbidities. To assess whether FHL2 is indeed actively involved in aging, we need to unravel its manner of action in this complicated process in greater detail using dedicated mouse models, human databases and primary cell lines.

Author Contributions: J.J.H. and M.P.C.-O. were involved in conceptualization, preparation of the original draft, editing, and visualization of the manuscript. C.J.d.V. was involved in conceptualization, editing, supervision of the manuscript, and funding acquisition. All authors have read and agreed to the published version of the manuscript.

Funding: This research was funded by Amsterdam Cardiovascular Sciences grant number ACSOIO-call-2017-5792, and Rembrandt Institute Cardiovascular Sciences grant number RICS-2013-08 to $\mathrm{CdV}$.

Institutional Review Board Statement: Not applicable.

Informed Consent Statement: Not applicable.

Data Availability Statement: Not applicable.

Acknowledgments: We would like to thank Dave Speijer for his critical reading of the review. We would also like to thank the members of our laboratory for stimulating discussions. 
Conflicts of Interest: The authors declare no conflict of interest.

\section{References}

1. Bach, I. The LIM domain: Regulation by association. Mech. Dev. 2000, 91, 5-17. [CrossRef]

2. Jumper, J.; Evans, R.; Pritzel, A.; Green, T.; Figurnov, M.; Ronneberger, O.; Tunyasuvunakool, K.; Bates, R.; Žídek, A.; Potapenko, A.; et al. Highly accurate protein structure prediction with AlphaFold. Nature 2021, 596, 583-589. [CrossRef] [PubMed]

3. Orii, N.; Ganapathiraju, M.K. Wiki-Pi: A Web-Server of Annotated Human Protein-Protein Interactions to Aid in Discovery of Protein Function. PLoS ONE 2012, 7, e49029. [CrossRef] [PubMed]

4. Tran, M.K.; Kurakula, K.; Koenis, D.S.; de Vries, C.J.M. Protein-protein interactions of the LIM-only protein FHL2 and functional implication of the interactions relevant in cardiovascular disease. Biochim. Biophys. Acta Mol. Cell Res. 2016, 1863, $219-228$. [CrossRef] [PubMed]

5. $\quad$ Chen, C.Y.; Tsai, H.Y.; Tsai, S.H.; Chu, P.H.; Huang, P.H.; Chen, J.W.; Lin, S.J. Deletion of the FHL2 gene attenuates intima-media thickening in a partially ligated carotid artery ligated mouse model. J. Cell. Mol. Med. 2020, 24, 160-173. [CrossRef] [PubMed]

6. Liang, Y.; Bradford, W.H.; Zhang, J.; Sheikh, F. Four and a half LIM domain protein signaling and cardiomyopathy. Biophys. Rev. 2018, 10, 1073-1085. [CrossRef] [PubMed]

7. Liu, Z.; Han, S.; Wang, Y.; Cui, C.; Zhu, Q.; Jiang, X.; Yang, C.; Du, H.; Yu, C.; Li, Q.; et al. The LIM-only protein FHL2 is involved in autophagy to regulate the development of skeletal muscle cell. Int. J. Biol. Sci. 2019, 15, 838-846. [CrossRef]

8. van de Pol, V.; Vos, M.; DeRuiter, M.C.; Goumans, M.J.; de Vries, C.J.M.; Kurakula, K. LIM-only protein FHL2 attenuates inflammation in vascular smooth muscle cells through inhibition of the NFkB pathway. Vascul. Pharmacol. 2020, 125-126, 106634. [CrossRef]

9. Jin, X.; Jiao, X.; Jiao, J.; Zhang, T.; Cui, B. Increased expression of FHL2 promotes tumorigenesis in cervical cancer and is correlated with poor prognosis. Gene 2018, 669, 99-106. [CrossRef] [PubMed]

10. Sun, L.; Yu, S.; Xu, H.; Zheng, Y.; Lin, J.; Wu, M.; Wang, J.; Wang, A.; Lan, Q.; Furnari, F.; et al. FHL2 interacts with EGFR to promote glioblastoma growth. Oncogene 2018, 37, 1386-1398. [CrossRef]

11. Verset, L.; Feys, L.; Trépant, A.L.; De Wever, O.; Demetter, P. FHL2: A scaffold protein of carcinogenesis, tumour-stroma interactions and treatment response. Histol. Histopathol. 2016, 31, 469-478. [CrossRef] [PubMed]

12. Wang, C.; Lv, X.; He, C.; Davis, J.S.; Wang, C.; Hua, G. Four and a half lim domains 2 (FHL2) contribute to the epithelial ovarian cancer carcinogenesis. Int. J. Mol. Sci. 2020, 21, 7751. [CrossRef] [PubMed]

13. Chu, P.-H.; Bardwell, W.M.; Gu, Y.; Ross, J.; Chen, J. FHL2 (SLIM3) Is Not Essential for Cardiac Development and Function. Mol. Cell. Biol. 2000, 20, 7460-7462. [CrossRef]

14. Neuman, N.A.; Ma, S.; Schnitzler, G.R.; Zhu, Y.; Lagna, G.; Hata, A. The four-and-a-half LIM domain protein 2 regulates vascular smooth muscle phenotype and vascular tone. J. Biol. Chem. 2009, 284, 13202-13212. [CrossRef]

15. Purcell, N.H.; Darwis, D.; Bueno, O.F.; Müller, J.M.; Schüle, R.; Molkentin, J.D. Extracellular Signal-Regulated Kinase 2 Interacts with and Is Negatively Regulated by the LIM-Only Protein FHL2 in Cardiomyocytes. Mol. Cell. Biol. 2004, 24, 1081-1095. [CrossRef]

16. Clemente-Olivo, M.P.; Habibe, J.J.; Vos, M.; Ottenhoff, R.; Jongejan, A.; Herrema, H.; Zelcer, N.; Kooijman, S.; Rensen, P.C.N.; van Raalte, D.H.; et al. Four-and-a-half LIM domain protein 2 (FHL2) deficiency protects mice from diet-induced obesity and high FHL2 expression marks human obesity. Metabolism 2021, 121, 154815. [CrossRef]

17. Ng, C.F.; Zhou, W.J.W.; Ng, P.K.S.; Li, M.S.; Ng, Y.K.; Lai, P.B.S.; Tsui, S.K.W. Characterization of human FHL2 transcript variants and gene expression regulation in hepatocellular carcinoma. Gene 2011, 481, 41-47. [CrossRef]

18. Bai, S.; Zha, J.; Zhao, H.; Ross, F.P.; Teitelbaum, S.L. Tumor necrosis factor receptor-associated factor 6 is an intranuclear transcriptional coactivator in osteoclasts. J. Biol. Chem. 2008, 283, 30861-30867. [CrossRef]

19. Lv, H.; Zhang, M.; Shang, Z.; Li, J.; Zhang, S.; Lian, D.; Zhang, R. Genome-wide haplotype association study identify the FGFR2 gene as a risk gene for Acute Myeloid Leukemia. Oncotarget 2017, 8, 7891-7899. [CrossRef] [PubMed]

20. McKay, J.D.; Hung, R.J.; Han, Y.; Zong, X.; Carreras-Torres, R.; Christiani, D.C.; Caporaso, N.E.; Johansson, M.; Xiao, X.; Li, Y.; et al. Large-scale association analysis identifies new lung cancer susceptibility loci and heterogeneity in genetic susceptibility across histological subtypes. Nat. Genet. 2017, 49, 1126-1132. [CrossRef] [PubMed]

21. Howard, D.M.; Adams, M.J.; Shirali, M.; Clarke, T.K.; Marioni, R.E.; Davies, G.; Coleman, J.R.I.; Alloza, C.; Shen, X.; Barbu, M.C.; et al. Genome-wide association study of depression phenotypes in UK Biobank identifies variants in excitatory synaptic pathways. Nat. Commun. 2018, 9, 1-10. [CrossRef]

22. Palumbo, D.; Affinito, O.; Monticelli, A.; Cocozza, S. DNA Methylation variability among individuals is related to CpGs cluster density and evolutionary signatures. BMC Genomics 2018, 19, 229. [CrossRef] [PubMed]

23. Ciccarone, F.; Tagliatesta, S.; Caiafa, P.; Zampieri, M. DNA methylation dynamics in aging: How far are we from understanding the mechanisms? Mech. Ageing Dev. 2018, 174, 3-17. [CrossRef]

24. Jung, S.E.; Lim, S.M.; Hong, S.R.; Lee, E.H.; Shin, K.J.; Lee, H.Y. DNA methylation of the ELOVL2, FHL2, KLF14, C1orf132/MIR29B2C, and TRIM59 genes for age prediction from blood, saliva, and buccal swab samples. Forensic Sci. Int. Genet. 2019, 38, 1-8. [CrossRef]

25. Lee, H.Y.; Hong, S.R.; Lee, J.E.; Hwang, I.K.; Kim, N.Y.; Lee, J.M.; Fleckhaus, J.; Jung, S.E.; Lee, Y.H. Epigenetic age signatures in bones. Forensic Sci. Int. Genet. 2020, 46, 102261. [CrossRef] [PubMed] 
26. Zbieć-Piekarska, R.; Spólnicka, M.; Kupiec, T.; Parys-Proszek, A.; Makowska, Z.; Pałeczka, A.; Kucharczyk, K.; Płoski, R.; Branicki, W. Development of a forensically useful age prediction method based on DNA methylation analysis. Forensic Sci. Int. Genet. 2015, 17, 173-179. [CrossRef]

27. Genini, M. Subtractive cloning and characterization of DRAL, a novel LIM-domain protein down-regulated in Rhabdomyosarcoma. DNA Cell Biol. 1997, 16, 433-442. [CrossRef]

28. Kong, Y.; Shelton, J.M.; Rothermel, B.; Li, X.; Richardson, J.A.; Bassel-Duby, R.; Williams, R.S. Cardiac-specific LIM protein FHL2 modifies the hypertrophic response to $\beta$-adrenergic stimulation. Circulation 2001, 103, 2731-2738. [CrossRef]

29. Arimura, T.; Hayashi, T.; Matsumoto, Y.; Shibata, H.; Hiroi, S.; Nakamura, T.; Inagaki, N.; Hinohara, K.; Takahashi, M.; Manatsu, S.I.; et al. Structural analysis of four and half LIM protein-2 in dilated cardiomyopathy. Biochem. Biophys. Res. Commun. 2007, 357, 162-167. [CrossRef]

30. Martin, B.; Schneider, R.; Janetzky, S.; Waibler, Z.; Pandur, P.; Kühl, M.; Behrens, J.; von der Mark, K.; Starzinski-Powitz, A.; Wixler, V. The LIM-only protein FHL2 interacts with $\beta$-catenin and promotes differentiation of mouse myoblasts. J. Cell Biol. 2002, 159, 113-122. [CrossRef]

31. Kim, S.Y.; Volkl, S.; Ludwig, S.; Schneider, H.; Wixler, V.; Park, J. Deficiency of Fhl2 leads to delayed neuronal cell migration and premature astrocyte differentiation. J. Cell Sci. 2019, 132, jcs228940. [CrossRef]

32. Johannessen, M.; Møler, S.; Hansen, T.; Moens, U.; Van Ghelue, M. The multifunctional roles of the four-and-a-half-LIM only protein FHL2. Cell. Mol. Life Sci. 2006, 63, 268-284. [CrossRef] [PubMed]

33. Chu, P.H.; Yeh, L.K.; Lin, H.C.; Jung, S.M.; Ma, D.H.K.; Wang, I.J.; Wu, H.H.; Shiu, T.F.; Chen, J. Deletion of the FHL2 gene attenuating neovascularization after corneal injury. Investig. Ophthalmol. Vis. Sci. 2008, 49, 5314-5318. [CrossRef] [PubMed]

34. Huss, S.; Stellmacher, C.; Goltz, D.; Khlistunova, I.; Adam, A.C.; Trebicka, J.; Kirfel, J.; Büttner, R.; Weiskirchen, R. Deficiency in four and one half LIM domain protein 2 (FHL2) aggravates liver fibrosis in mice. BMC Gastroenterol. 2013, 13, 8. [CrossRef] [PubMed]

35. Nouët, Y.; Dahan, J.; Labalette, C.; Levillayer, F.; Julien, B.; Jouvion, G.; Cairo, S.; Vives, F.L.; Ribeiro, A.; Huerre, M.; et al. The four and a half LIM-only protein 2 regulates liver homeostasis and contributes to carcinogenesis. J. Hepatol. 2012, 57, 1029-1036. [CrossRef]

36. Sommer, J.; Dorn, C.; Gäbele, E.; Bataille, F.; Freese, K.; Seitz, T.; Thasler, W.E.; Büttner, R.; Weiskirchen, R.; Bosserhoff, A.; et al Four-And-A-Half LIM-Domain Protein 2 (FHL2) Deficiency Aggravates Cholestatic Liver Injury. Cells 2020, 9, 248. [CrossRef] [PubMed]

37. Li, S.Y.; Huang, P.H.; Tarng, D.C.; Lin, T.P.; Yang, W.C.; Chang, Y.H.; Yang, A.H.; Lin, C.C.; Yang, M.H.; Chen, J.W.; et al. Four-and-a-half LIM domains protein 2 is a coactivator of Wnt signaling in diabetic kidney disease. J. Am. Soc. Nephrol. 2015, 26, 3072-3084. [CrossRef]

38. Ebrahimian, T.; Dierick, F.; Simon, D.; Heidari, M.; Orthwein, A.; Mann, K.K.; Lehoux, S. FHL2 Is Essential for Spleen T Cell-Dependent B Cell Activation and Antibody Response. ImmunoHorizons 2020, 4, 259-273. [CrossRef]

39. Wixler, V. The role of FHL2 in wound healing and inflammation. FASEB J. 2019, 33, 7799-7809. [CrossRef]

40. Chu, P.H.; Yeh, H.I.; Wu, H.H.; Hong, R.C.; Shiu, T.F.; Yang, C.M. Deletion of the FHL2 gene attenuates the formation of atherosclerotic lesions after a cholesterol-enriched diet. Life Sci. 2010, 86, 365-371. [CrossRef]

41. Ebrahimian, T.; Simon, D.; Lemarié, C.A.; Simeone, S.; Heidari, M.; Mann, K.K.; Wassmann, S.; Lehoux, S. Absence of Four-anda-Half LIM domain protein 2 decreases atherosclerosis in ApoE-/- Mice. Arterioscler. Thromb. Vasc. Biol. 2015, 35, 1190-1197. [CrossRef] [PubMed]

42. Kurakula, K.; Sommer, D.; Sokolovic, M.; Moerland, P.D.; Scheij, S.; van Loenen, P.B.; Koenis, D.S.; Zelcer, N.; van Tiel, C.M.; de Vries, C.J.M. LIM-Only Protein FHL2 Is a Positive Regulator of Liver X Receptors in Smooth Muscle Cells Involved in Lipid Homeostasis. Mol. Cell. Biol. 2015, 35, 52-62. [CrossRef]

43. Rönn, T.; Volkov, P.; Gillberg, L.; Kokosar, M.; Perfilyev, A.; Jacobsen, A.L.; Jørgensen, S.W.; Brøns, C.; Jansson, P.A.; Eriksson, K.F.; et al. Impact of age, BMI and HbA1c levels on the genome-wide DNA methylation and mRNA expression patterns in human adipose tissue and identification of epigenetic biomarkers in blood. Hum. Mol. Genet. 2015, 24, 3792-3813. [CrossRef] [PubMed]

44. Cao, C.Y.; Mok, S.W.F.; Cheng, V.W.S.; Tsui, S.K.W. The FHL2 regulation in the transcriptional circuitry of human cancers. Gene 2015, 572, 1-7. [CrossRef] [PubMed]

45. Kleiber, K.; Strebhardt, K.; Martin, B.T. The biological relevance of FHL2 in tumour cells and its role as a putative cancer target. Anticancer Res. 2007, 27, 55-61. [PubMed]

46. Hua, G.; He, C.; Lv, X.; Fan, L.; Wang, C.; Remmenga, S.W.; Rodabaugh, K.J.; Yang, L.; Lele, S.M.; Yang, P.; et al. The four and a half LIM domains 2 (FHL2) regulates ovarian granulosa cell tumor progression via controlling AKT1 transcription. Cell Death Dis. 2016, 7, e2297. [CrossRef] [PubMed]

47. Martin, B.T.; Kleiber, K.; Wixler, V.; Raab, M.; Zimmer, B.; Kaufmann, M.; Strebhardt, K. FHL2 regulates cell cycle-dependent and doxorubicin-induced p21 Cip1/Waf1 expression in breast cancer cells. Cell Cycle 2007, 6, 1779-1788. [CrossRef]

48. McGrath, M.J.; Binge, L.C.; Sriratana, A.; Wang, H.; Robinson, P.A.; Pook, D.; Fedele, C.G.; Brown, S.; Dyson, J.M.; Cottle, D.L.; et al. Regulation of the transcriptional coactivator FHL2 licenses activation of the androgen receptor in castrate-resistant prostate cancer. Cancer Res. 2013, 73, 5066-5079. [CrossRef] 
49. Kahl, P.; Gullotti, L.; Heukamp, L.C.; Wolf, S.; Friedrichs, N.; Vorreuther, R.; Solleder, G.; Bastian, P.J.; Ellinger, J.; Metzger, E.; et al. Androgen receptor coactivators lysine-specific histone demethylase 1 and four and a half LIM domain protein 2 predict risk of prostate cancer recurrence. Cancer Res. 2006, 66, 11341-11347. [CrossRef]

50. Xu, J.; Zhou, J.; Li, M.S.; Ng, C.F.; Ng, Y.K.; Lai, P.B.S.; Tsui, S.K.W. Transcriptional regulation of the tumor suppressor FHL2 by p53 in human kidney and liver cells. PLoS ONE 2014, 9, e99359. [CrossRef]

51. Wang, Q.; Wang, X.; Tian, X.; Tang, R.; Xu, X. Four and a half LIM domains 2 contributes to the development of human tongue squamous cell carcinoma. J. Mol. Histol. 2016, 47, 105-116. [CrossRef]

52. Qiao, L.; Wang, Y.; Pang, R.; Wang, J.; Dai, Y.; Ma, J.; Gu, Q.; Li, Z.; Zhang, Y.; Zou, B.; et al. Oncogene functions of FHL2 are independent from NF-кBI $\alpha$ in gastrointestinal cancer. Pathol. Oncol. Res. 2009, 15, 31-36. [CrossRef] [PubMed]

53. Labalette, C.; Nouët, Y.; Levillayer, F.; Colnot, S.; Chen, J.; Claude, V.; Huerre, M.; Perret, C.; Buendia, M.A.; Wei, Y. Deficiency of the LIM-only protein FHL2 reduces intestinal tumorigenesis in Apc Mutant Mice. PLoS ONE 2010, 5, e10371. [CrossRef] [PubMed]

54. Guo, Z.; Zhang, W.; Xia, G.; Niu, L.; Zhang, Y.; Wang, X.; Zhang, Y.; Jiang, B.; Wang, J. Sp1 upregulates the Four and Half Lim 2 (FHL2) expression in gastrointestinal cancers through transcription regulation. Mol. Carcinog. 2010, 49, 826-836. [CrossRef]

55. Philippar, U.; Schratt, G.; Dieterich, C.; Müller, J.M.; Galgóczy, P.; Engel, F.B.; Keating, M.T.; Gertler, F.; Schüle, R.; Vingron, M.; et al. The SRF target gene Fhl2 antagonizes RhoA/MAL-dependent activation of SRF. Mol. Cell 2004, 16, 867-880. [CrossRef] [PubMed]

56. Morlon, A.; Sassone-Corsi, P. The LIM-only protein FHL2 is a serum-inducible transcriptional coactivator of AP-1. Proc. Natl. Acad. Sci. USA 2003, 100, 3977-3982. [CrossRef]

57. Kurakula, K.; Vos, M.; Logiantara, A.; Roelofs, J.J.T.H.; Nieuwenhuis, M.A.; Koppelman, G.H.; Postma, D.S.; Brandsma, C.A.; Sin, D.D.; Bossé, Y.; et al. Deficiency of FHL2 attenuates airway inflammation in mice and genetic variation associates with human bronchial hyper-responsiveness. Allergy Eur. J. Allergy Clin. Immunol. 2015, 70, 1531-1544. [CrossRef]

58. Bae, H.; Lunetta, K.L.; Murabito, J.M.; Andersen, S.L.; Schupf, N.; Perls, T.; Sebastiani, P. Genetic associations with age of menopause in familial longevity. Menopause 2019, 26, 1204-1212. [CrossRef]

59. Kroone, C.; Vos, M.; Rademakers, T.; Kuijpers, M.; Hoogenboezem, M.; Van Buul, J.; Heemskerk, J.W.M.; Ruf, W.; Van Hylckama Vlieg, A.; Versteeg, H.H.; et al. LIM-only protein FHL2 attenuates vascular tissue factor activity, inhibits thrombus formation in mice and FHL2 genetic variation associates with human venous thrombosis. Haematologica 2020, 105, 1677-1685. [CrossRef]

60. Tachmazidou, I.; Süveges, D.; Min, J.L.; Ritchie, G.R.S.; Steinberg, J.; Walter, K.; Iotchkova, V.; Schwartzentruber, J.; Huang, J.; Memari, Y.; et al. Whole-Genome Sequencing Coupled to Imputation Discovers Genetic Signals for Anthropometric Traits. Am. J. Hum. Genet. 2017, 100, 865-884. [CrossRef]

61. Zhu, Z.; Guo, Y.; Shi, H.; Liu, C.L.; Panganiban, R.A.; Chung, W.; O’Connor, L.J.; Himes, B.E.; Gazal, S.; Hasegawa, K.; et al. Shared genetic and experimental links between obesity-related traits and asthma subtypes in UK Biobank. J. Allergy Clin. Immunol. 2020, 145, 537-549. [CrossRef]

62. Kichaev, G.; Bhatia, G.; Loh, P.R.; Gazal, S.; Burch, K.; Freund, M.K.; Schoech, A.; Pasaniuc, B.; Price, A.L. Leveraging Polygenic Functional Enrichment to Improve GWAS Power. Am. J. Hum. Genet. 2019, 104, 65-75. [CrossRef]

63. Friedrich, F.W.; Reischmann, S.; Schwalm, A.; Unger, A.; Ramanujam, D.; Münch, J.; Müller, O.J.; Hengstenberg, C.; Galve, E.; Charron, P.; et al. FHL2 expression and variants in hypertrophic cardiomyopathy. Basic Res. Cardiol. 2014, 109, 451. [CrossRef]

64. Ntalla, I.; Weng, L.C.; Cartwright, J.H.; Hall, A.W.; Sveinbjornsson, G.; Tucker, N.R.; Choi, S.H.; Chaffin, M.D.; Roselli, C.; Barnes, M.R.; et al. Multi-ancestry GWAS of the electrocardiographic PR interval identifies 202 loci underlying cardiac conduction. Nat. Commun. 2020, 11, 1-12. [CrossRef] [PubMed]

65. Chen, M.H.; Raffield, L.M.; Mousas, A.; Sakaue, S.; Huffman, J.E.; Moscati, A.; Trivedi, B.; Jiang, T.; Akbari, P.; Vuckovic, D.; et al. Trans-ethnic and Ancestry-Specific Blood-Cell Genetics in 746,667 Individuals from 5 Global Populations. Cell 2020, 182, 1198-1213. [CrossRef] [PubMed]

66. Vuckovic, D.; Bao, E.L.; Akbari, P.; Lareau, C.A.; Mousas, A.; Jiang, T.; Chen, M.H.; Raffield, L.M.; Tardaguila, M.; Huffman, J.E.; et al. The Polygenic and Monogenic Basis of Blood Traits and Diseases. Cell 2020, 182, 1214-1231.e11. [CrossRef]

67. Evangelou, E.; Warren, H.R.; Mosen-Ansorena, D.; Mifsud, B.; Pazoki, R.; Gao, H.; Ntritsos, G.; Dimou, N.; Cabrera, C.P.; Karaman, I.; et al. Genetic analysis of over 1 million people identifies 535 new loci associated with blood pressure traits. Nat. Genet. 2018, 50, 1412-1425. [CrossRef] [PubMed]

68. Bacos, K.; Gillberg, L.; Volkov, P.; Olsson, A.H.; Hansen, T.; Pedersen, O.; Gjesing, A.P.; Eiberg, H.; Tuomi, T.; Almgren, P.; et al. Blood-based biomarkers of age-associated epigenetic changes in human islets associate with insulin secretion and diabetes. Nat. Commun. 2016, 7, 11089. [CrossRef]

69. Qian, Z.; Mao, L.; Fernald, A.A.; Yu, H.; Luo, R.; Jiang, Y.; Anastasi, J.; Valk, P.J.; Delwel, R.; Le Beau, M.M. Enhanced expression of FHL2 leads to abnormal myelopoiesis in vivo. Leukemia 2009, 23, 1650-1657. [CrossRef]

70. Cheng, Z.; Dai, Y.; Pang, Y.; Jiao, Y.; Zhao, H.; Zhang, Z.; Qin, T.; Hu, N.; Zhang, Y.; Ke, X.; et al. Enhanced expressions of FHL2 and iASPP predict poor prognosis in acute myeloid leukemia. Cancer Gene Ther. 2019, 26, 17-25. [CrossRef]

71. Lu, W.; Yu, T.; Liu, S.; Li, S.; Li, S.; Liu, J.; Xu, Y.; Xing, H.; Tian, Z.; Tang, K.; et al. FHL2 interacts with iASPP and impacts the biological functions of leukemia cells. Oncotarget 2017, 8, 40885-40895. [CrossRef] [PubMed]

72. McLoughlin, P.; Ehler, E.; Carlile, G.; Licht, J.D.; Schäfer, B.W. The LIM-only protein DRAL/FHL2 interacts with and is a corepressor for the promyelocytic leukemia zinc finger protein. J. Biol. Chem. 2002, 277, 37045-37053. [CrossRef] 
73. Pasšliç, Z.; Greif, P.A.; Jurinoviç, V.; Mulaw, M.; Kakadia, P.M.; Tizazu, B.; Archangelo, L.F.; Krause, A.; Bohlander, S.K. FHL2 interacts with CALM and is highly expressed in acute erythroid leukemia. Blood Cancer J. 2011, 1, e42. [CrossRef]

74. Jones, P.A. Functions of DNA methylation: Islands, start sites, gene bodies and beyond. Nat. Rev. Genet. 2012, 13, 484-492. [CrossRef]

75. Smith, J.; Sen, S.; Weeks, R.J.; Eccles, M.R.; Chatterjee, A. Promoter DNA Hypermethylation and Paradoxical Gene Activation. Trends Cancer 2020, 6, 392-406. [CrossRef] [PubMed]

76. Horvath, S. DNA methylation age of human tissues and cell types. Genome Biol. 2013, 14, R115. [CrossRef] [PubMed]

77. Hannum, G.; Guinney, J.; Zhao, L.; Zhang, L.; Hughes, G.; Sadda, S.V.; Klotzle, B.; Bibikova, M.; Fan, J.B.; Gao, Y.; et al. Genome-wide Methylation Profiles Reveal Quantitative Views of Human Aging Rates. Mol. Cell 2013, 49, 359-367. [CrossRef] [PubMed]

78. Garagnani, P.; Bacalini, M.G.; Pirazzini, C.; Gori, D.; Giuliani, C.; Mari, D.; Di Blasio, A.M.; Gentilini, D.; Vitale, G.; Collino, S.; et al. Methylation of ELOVL2 gene as a new epigenetic marker of age. Aging Cell 2012, 11, 1132-1134. [CrossRef] [PubMed]

79. Correia Dias, H.; Cunha, E.; Corte Real, F.; Manco, L. Age prediction in living: Forensic epigenetic age estimation based on blood samples. Leg. Med. 2020, 47, 101763. [CrossRef]

80. Steegenga, W.T.; Boekschoten, M.V.; Lute, C.; Hooiveld, G.J.; De Groot, P.J.; Morris, T.J.; Teschendorff, A.E.; Butcher, L.M.; Beck, S.; Müller, M. Genome-wide age-related changes in DNA methylation and gene expression in human PBMCs. Age (Omaha) 2014, 36, 1523-1540. [CrossRef]

81. Kananen, L.; Marttila, S.; Nevalainen, T.; Jylhävä, J.; Mononen, N.; Kähönen, M.; Raitakari, O.T.; Lehtimäki, T.; Hurme, M. Aging-associated DNA methylation changes in middle-aged individuals: The Young Finns study. BMC Genom. 2016, 17, 1-12. [CrossRef]

82. Correia Dias, H.; Cordeiro, C.; Corte Real, F.; Cunha, E.; Manco, L. Age Estimation Based on DNA Methylation Using Blood Samples From Deceased Individuals. J. Forensic Sci. 2020, 65, 465-470. [CrossRef]

83. Freire-Aradas, A.; Phillips, C.; Mosquera-Miguel, A.; Girón-Santamaría, L.; Gómez-Tato, A.; Casares De Cal, M.; Álvarez-Dios, J.; Ansede-Bermejo, J.; Torres-Español, M.; Schneider, P.M.; et al. Development of a methylation marker set for forensic age estimation using analysis of public methylation data and the Agena Bioscience EpiTYPER system. Forensic Sci. Int. Genet. 2016, 24, 65-74. [CrossRef]

84. Hamano, Y.; Manabe, S.; Morimoto, C.; Fujimoto, S.; Ozeki, M.; Tamaki, K. Forensic age prediction for dead or living samples by use of methylation-sensitive high resolution melting. Leg. Med. 2016, 21, 5-10. [CrossRef] [PubMed]

85. Cho, S.; Jung, S.E.; Hong, S.R.; Lee, E.H.; Lee, J.H.; Lee, S.D.; Lee, H.Y. Independent validation of DNA-based approaches for age prediction in blood. Forensic Sci. Int. Genet. 2017, 29, 250-256. [CrossRef] [PubMed]

86. Dias, H.C.; Cordeiro, C.; Pereira, J.; Pinto, C.; Real, F.C.; Cunha, E.; Manco, L. DNA methylation age estimation in blood samples of living and deceased individuals using a multiplex SNaPshot assay. Forensic Sci. Int. 2020, 311, 110267. [CrossRef] [PubMed]

87. Woźniak, A.; Heidegger, A.; Piniewska-Róg, D.; Pośpiech, E.; Xavier, C.; Pisarek, A.; Kartasińska, E.; Boroń, M.; Freire-Aradas, A.; Wojtas, M.; et al. Development of the VISAGE enhanced tool and statistical models for epigenetic age estimation in blood, buccal cells and bones. Aging (Albany. N. Y.) 2021, 13, 6459-6484. [CrossRef]

88. Giuliani, C.; Cilli, E.; Bacalini, M.G.; Pirazzini, C.; Sazzini, M.; Gruppioni, G.; Franceschi, C.; Garagnani, P.; Luiselli, D. Inferring chronological age from DNA methylation patterns of human teeth. Am. J. Phys. Anthropol. 2016, 159, 585-595. [CrossRef]

89. Turner, D.C.; Gorski, P.P.; Maasar, M.F.; Seaborne, R.A.; Baumert, P.; Brown, A.D.; Kitchen, M.O.; Erskine, R.M.; Dos-Remedios, I.; Voisin, S.; et al. DNA methylation across the genome in aged human skeletal muscle tissue and muscle-derived cells: The role of HOX genes and physical activity. Sci. Rep. 2020, 10, 1-19. [CrossRef]

90. Spólnicka, M.; Pośpiech, E.; Pepłońska, B.; Zbieć-Piekarska, R.; Makowska, Ż.; Pięta, A.; Karłowska-Pik, J.; Ziemkiewicz, B.; Wężyk, M.; Gasperowicz, P.; et al. DNA methylation in ELOVL2 and C1orf132 correctly predicted chronological age of individuals from three disease groups. Int. J. Legal Med. 2018, 132, 1-11. [CrossRef]

91. Li, J.; Zhu, X.; Yu, K.; Jiang, H.; Zhang, Y.; Wang, B.; Liu, X.; Deng, S.; Hu, J.; Deng, Q.; et al. Exposure to polycyclic aromatic hydrocarbons and accelerated DNA methylation aging. Environ. Health Perspect. 2018, 126, 067005. [CrossRef] [PubMed]

92. Bacalini, M.G.; Deelen, J.; Pirazzini, C.; De Cecco, M.; Giuliani, C.; Lanzarini, C.; Ravaioli, F.; Marasco, E.; Van Heemst, D.; Suchiman, H.E.D.; et al. Systemic Age-Associated DNA Hypermethylation of ELOVL2 Gene: In Vivo and in Vitro Evidences of a Cell Replication Process. J. Gerontol. Ser. A Biol. Sci. Med. Sci. 2017, 72, 1015-1023. [CrossRef] [PubMed]

93. Bysani, M.; Perfilyev, A.; De Mello, V.D.; Rönn, T.; Nilsson, E.; Pihlajamäki, J.; Ling, C. Epigenetic alterations in blood mirror age-associated DNA methylation and gene expression changes in human liver. Epigenomics 2017, 9, 105-122. [CrossRef] [PubMed]

94. Johansson, Å.; Enroth, S.; Gyllensten, U. Continuous Aging of the Human DNA Methylome Throughout the Human Lifespan. PLoS ONE 2013, 8, e67378. [CrossRef] [PubMed]

95. Taniguchi, I.; Iwaya, C.; Ohnaka, K.; Shibata, H.; Yamamoto, K. Genome-wide DNA methylation analysis reveals hypomethylation in the low-CpG promoter regions in lymphoblastoid cell lines. Hum. Genom. 2017, 11, 8. [CrossRef]

96. Wan, J.; Oliver, V.F.; Wang, G.; Zhu, H.; Zack, D.J.; Merbs, S.L.; Qian, J. Characterization of tissue-specific differential DNA methylation suggests distinct modes of positive and negative gene expression regulation. BMC Genom. 2015, 16, 49. [CrossRef] 